\title{
Testicular Tumors: A 15-Year Archive Review and Histopathological Evaluation
}

\section{Testis Tümörleri: 15 Yıllık Arşiv Taraması ve Histopatolojik Değerlendirilmesi}

\author{
Akgül Arıcı', @Elif Akçay', @Mümine Görmez', @Faik Alev Deresoy', @Fikret Erdemir², \\ Reşit Doğan Köseoğlu'
}

'Tokat Gaziosmanpaşa University, School of Medicine, Department of Medical Pathology, Tokat, Turkey ${ }^{2}$ Tokat Gaziosmanpaşa University, School of Medicine, Department of Urology, Tokat, Turkey

\begin{abstract}
Aim: Testicular tumors are one of the most common malignancies in men in the age group of 15-40 years, although they are rarely observed. In our study, it was aimed to evaluate their histopathological features by retrospectively examining of the cases diagnosed as testicular tumor in our department.

Material and Method: Age, tumor localization, tumor size, pathological stage, tumor type and frozen information of 65 cases diagnosed as testicular tumor in the Department of Medical Pathology at Tokat Gaziosmanpasa University Faculty of Medicine between 2006-2020 were examined.

Results: The mean age of 65 cases diagnosed as tumor was $37.9 \pm 17.73$ years. Their ages ranged from 1 to 78 years. Macroscopic tumor diameter was an average of $4.6 \pm 2.36 \mathrm{~cm}, 36$ (55.4\%) of them were located in the right and $29(44.6 \%)$ of them were located in the left testis. Histopathological diagnosis was germ cell tumor in $53(81.7 \%)$ cases and non-germ cell tumor in $12(18.3 \%)$ cases. The most common tumor was seminoma with 22 (33.9\%) cases and the second was mixed germ cell tumor with 19 (29.3\%) cases. In components forming mixed germ cell tumors, embryonal carcinoma was the most commonly seen. Intraoperative frozen section examination was performed in 17 cases, it was determined that 10 cases were malignant and 7 cases were benign.

Conclusion: The histopathological and general features of our series of testicular tumor was determined to be compatible with the literature to a great extent. Intraoperative frozen section examination is an important auxiliary diagnostic method in terms of organ preserving surgery.
\end{abstract}

Keywords: Testis, tumor, germ cell, frozen section examination, testis preserving surgery
Öz

Amaç: Testis tümörleri nadir görülmekle birlikte, 15-40 yaş grubundaki erkeklerde en sık görülen malignitelerden biridir. Çalışmamızda bölümümüzde testis tümörü tanısı almış olguların retrospektif olarak incelenip, histopatolojik özelliklerinin değerlendirilmesi amaçlandı.

Gereç ve Yöntem: 2006-2020 yılları arasında Tokat Gaziosmanpaşa Üniversitesi Tıp Fakültesi Tıbbi Patoloji Anabilim Dalı'nda testis tümörü tanısı alan 65 olgunun yaş, tümör lokalizasyonu, tümör boyutu, patolojik evre, tümör tipi ve frozen bilgisi incelendi.

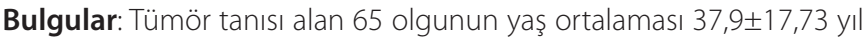
idi. Yaşları 1-78 yıl arasında değişmekteydi. Makroskopik tümör çapı

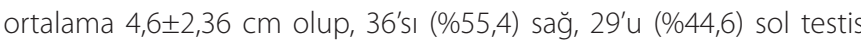
lokalizasyonluydu. Histopatolojik tanı 53 olguda $(\% 81,7)$ germ hücreli tümör ve 12 olguda $(\% 18,3)$ germ hücreli dışı tümördü. En sık görülen tümör 22 olgu $(\% 33,9)$ ile seminom ve ikinci sıklıkta 19 olgu $(\% 29,3)$ ile mikst germ hücreli tümördü. Mikst germ hücreli tümörleri oluşturan komponentlerde en sık embriyonel karsinom görüldü. İntraoperatif frozen kesit inceleme 17 olguda yapılmış olup, 10 olgunun malign, 7 olgunun benign olduğu saptandı.

Sonuç: Testis tümörü serimizin histopatolojik ve genel özelliklerinin büyük oranda literatür ile uyumlu olduğu saptanmıştır. İntraoperatif frozen inceleme organ koruyucu cerrahi açısından önemli bir yardımcı tanı yöntemidir.

Anahtar Kelimeler: Testis, tümör, germ hücre, frozen kesit inceleme, testis koruyucu cerrahi 


\section{INTRODUCTION}

Testicular tumors are one of the most common seen malignancies in men in the age group of 15-40 years, although they are rarely observed. It constitutes $1-2 \%$ of all malignancies in men. The age standardized incidence rate of testicular cancer was 1,5 per 100000 people in the world. It is more commonly seen in developed countries and its incidence is increasing day by day. As the highest incidence rate is 7.2-8.7 in Europe, the lowest incidence rate is 0.3-0.6 in Africa and 0.4-1.7 in Asia. ${ }^{[1,2]}$ Etiopathogenesis has not been fully elucidated. However, environmental and genetic factors are blamed in the etiology. Family history, undescended testis, testicular microlithiasis, inguinal hernia, low birth weight, maternal smoking during pregnancy, high-fat diet, obesity, occupational exposures are supposed among the risk factors. ${ }^{[3,4]}$ Patients with testicular tumors usually present with a unilateral painless mass. The tumors are more commonly observed in the right testis than the left one. The incidence of bilaterality is reported to be at rate of 1-4\%. ${ }^{[5,6]}$ Germ cell tumors (GCTs) constitute $95 \%$ of testicular tumors. GCTs are divided into two main groups as seminomatous and nonseminomatous GCTs. Seminomas make up 50\% of all GCTs. Nonseminomatous GCTs include embryonal carcinoma (EC), yolk sac tumor (YST), choriocarcinoma (CC) and teratoma (T). Non-germ cell tumors (NGCTs) of the testis are classified as sex cord-stromal tumors paratesticular tumors, mesenchymal tumors of the spermatic cord and testicular adnexa, hematolymphoid tumors and metastatic tumors. $^{[3,4]}$ In The World Health Organization (WHO) 2016 classification of testicular tumors, different from the WHO 2004 classification, germ cell tumors are defined as the tumors derived from germ cell neoplasia in situ and the tumors unrelated to germ cell neoplasia in situ. ${ }^{[3,7]}$

In our study, we aimed to examine the age, tumor location, tumor size, pathological stage, tumor type and frozen information of cases diagnosed as testicular tumor in our department between 2006-2020, and to evaluate them in the light of literature information.

\section{MATERIAL AND METHOD}

A total of 65 cases who were diagnosed as testicular tumor by performing histopathological examination in the Department of Medical Pathology between 2006-2020, were analyzed after obtaining the approval of the Clinical Research Ethics Committee (20-KAEK-320) at Tokat Gaziosmanpaşa University Faculty of Medicine for our study. Pathology reports of the cases were analyzed retrospectively by scanning the pathology archive. Hematoxylin-eosin stained preparations of the cases were reviewed and classified according to the WHO 2016 classification. Age, tumor localization, tumor size, tumor type, pathological stage and frozen information of the cases were registered from the pathology reports and the records in the automation system. The obtained data were evaluated in the light of literature information.
Statistically, categorical measurements were specified as numbers and percentages, and continuous measurements were expressed as mean and standard deviation (median and minimum-maximum where necessary). SPSS 22 package software was used for the analysis.

\section{RESULTS}

Testicular tumors were detected in 65 (42.8\%) of 152 orchiectomy materials from 2006-2020, which were retrospectively detected from our department archive. The ages of 65 patients diagnosed as tumor ranged from 1 to 78 years and the mean age was found to be $37.9 \pm 17.73$ years. The age range distribution of the patients was given in Figure 1. Macroscopic tumor diameters ranged from 0.8 to $10 \mathrm{~cm}$, with an average of $4.6 \pm 2.36 \mathrm{~cm} .36(55.4 \%)$ of the tumors were located in the right, 29 (44.6\%) of them were located in the left testis. Bilateral testicular involvement was not present in any of the patients. Fify three $(81.7 \%)$ of our cases were diagnosed as GCT and 12 (18.3\%) of them as NGCT. The histopathological distribution of our cases diagnosed as testicular tumor was given in Table 1. The most common tumor among our cases was seminoma with 22 (33.9\%) cases (Figure 2) and the second most common tumor was mixed GCT with 19 (29.3\%) cases. In the components forming mixed GCTs, EC (Figure 3) was the most common seen. The distribution of mixed GCTs and constituent components was shown in Table 2. In our series, there were 17 cases who underwent intraoperative frozen section examination. The characteristics of these cases were given in Table $\mathbf{3}$. Intraoperative frozen section examination was performed in 17 cases, it was determined that 10 cases were malignant and 7 cases were benign. All cases diagnosed as epidermoid cyst were the cases which underwent intraoperative frozen section examination. Of the cases with pathological tumor staging, 31 were found to be pT1, 18 were pT2, and 4 were pT3. Six of our patients became exitus. Two of them had a diagnosis of GCT and the others consisted of one patient each who had a diagnosis of lymphoma, leiomyosarcoma, adenomatoid tumor and malignant melanoma metastasis.

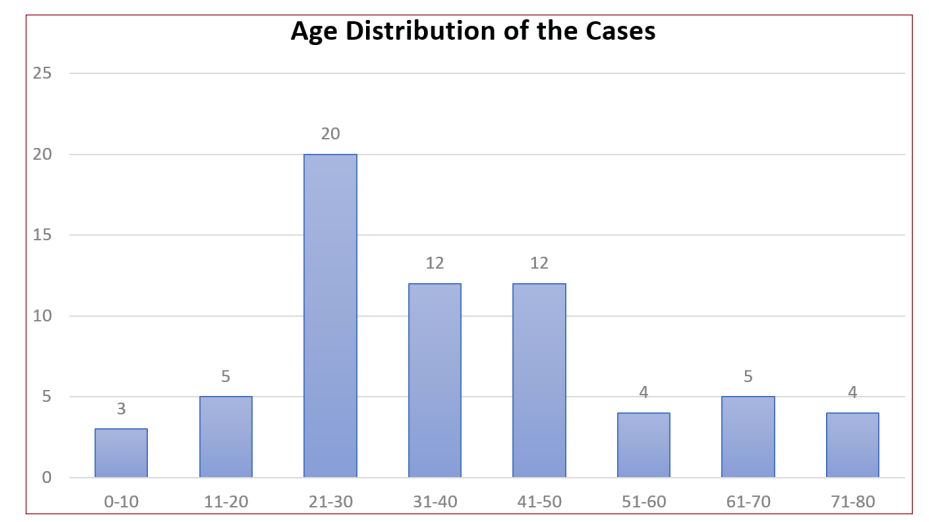

Figure 1. The age distribution of the patients with testicular tumors 


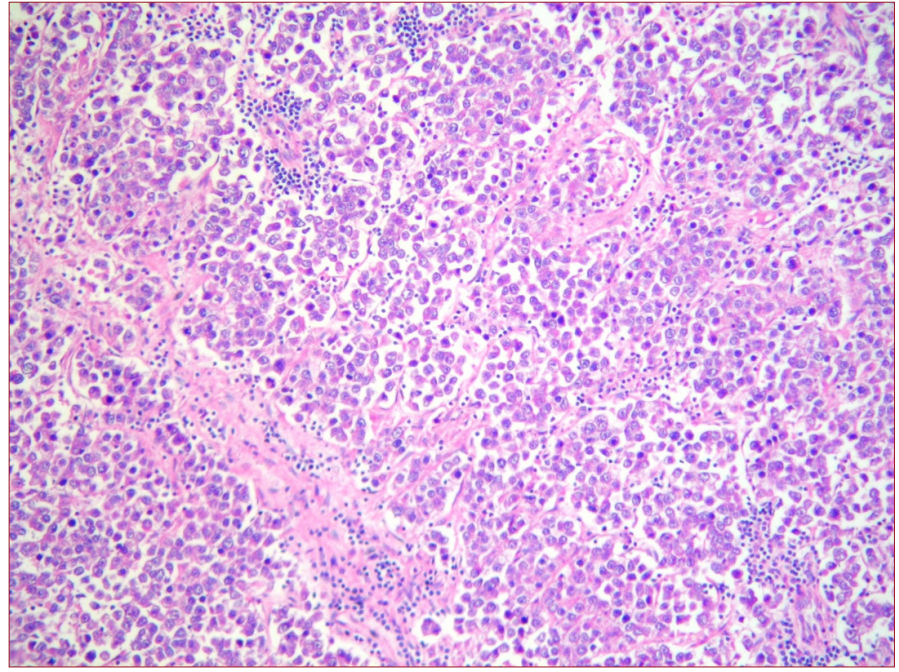

Figure 2. Seminoma. Lymphocytic infiltration between polygonal shaped tumor cells with prominent nucleoli and eosinophilic cytoplasm. (HE x 100)

\section{Table 1. Histopathological distribution of testicular tumors}

\begin{tabular}{|c|c|c|}
\hline Diagnosis & $\mathbf{n}$ & $\%$ \\
\hline \multicolumn{3}{|l|}{ Germ cell tumors } \\
\hline Seminoma & 22 & 33.9 \\
\hline Embryonal carcinoma & 1 & 1.5 \\
\hline Yolk sac tumor & 3 & 4.7 \\
\hline Choriocarcinoma & 1 & 1.5 \\
\hline Teratoma & 1 & 1.5 \\
\hline Mixed GCT & 19 & 29.3 \\
\hline Spermatocytic tumor & 1 & 1.5 \\
\hline Epidermoid cyst & 5 & 7.8 \\
\hline \multicolumn{3}{|l|}{ Sex cord-stromal tumor } \\
\hline Leydig cell tumor & 2 & 3.1 \\
\hline \multicolumn{3}{|l|}{ Hematolymphoid tumors } \\
\hline Diffuse large B-cell lymphoma & 4 & 6.2 \\
\hline \multicolumn{3}{|l|}{ Paratesticular tumors } \\
\hline Adenomatoid tumor & 1 & 1.5 \\
\hline \multicolumn{3}{|c|}{ Mesenchymal tumors of the spermatic cord and testicular adnexa } \\
\hline Leiomyoma & 1 & 1.5 \\
\hline Leiomyosarcoma & 1 & 1.5 \\
\hline Hemangioma & 1 & 1.5 \\
\hline \multicolumn{3}{|l|}{ Metastatic tumors } \\
\hline Malignant melanoma metastasis & 1 & 1.5 \\
\hline Renal cell carcinoma metastasis & 1 & 1.5 \\
\hline Total & 65 & 100 \\
\hline
\end{tabular}

\section{Table 2. Distribution of mixed GCTs}

\begin{tabular}{lcc} 
Tanı & $\mathbf{n}$ & $\%$ \\
\hline EC+YST+T & 6 & 31.5 \\
S+EC & 4 & 21 \\
S+EC+YST & 3 & 15.7 \\
EC+YST & 1 & 5.3 \\
EC+T & 1 & 5.3 \\
S+YST & 1 & 5.3 \\
S+YST+T & 1 & 5.3 \\
S+EC+YST+T & 1 & 5.3 \\
S+EC+T+CC & 1 & 5.3 \\
Total & 19 & 100 \\
\hline EC: Embryonal carcinoma, YST: Yolk sac tumor, T: Teratoma, S: Seminoma, CC: Choriocarcinoma
\end{tabular}

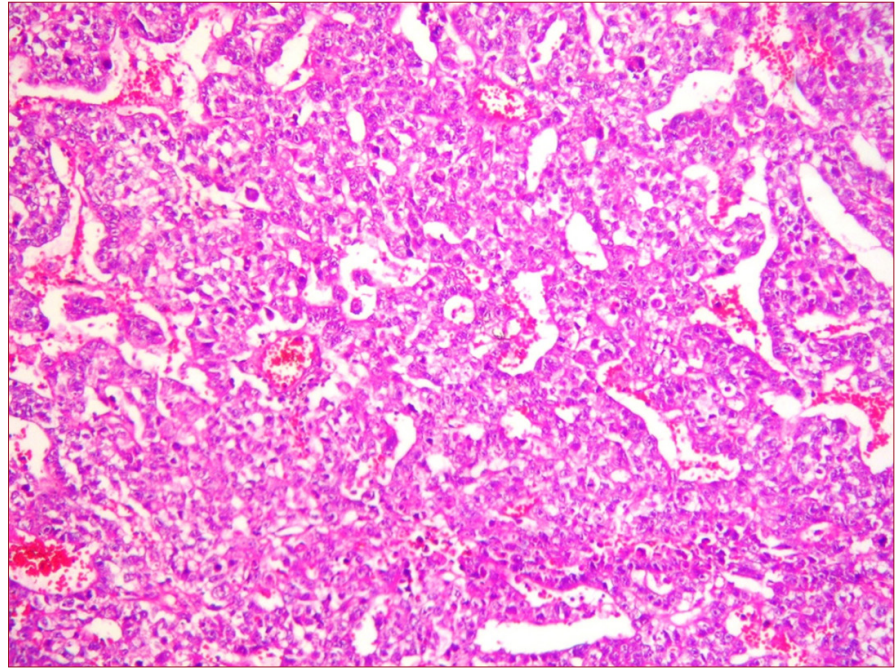

Figure 3. Embryonal carcinoma. Glandular pattern of columnar-shaped tumor cells. (HE x 100)

Table 3. Testicular tumors which intraoperative frozen section examination were performed in

\begin{tabular}{ccccc} 
Age & Localization & $\begin{array}{c}\text { Tumor } \\
\text { size } \mathbf{( c m})\end{array}$ & $\begin{array}{c}\text { Frozen section } \\
\text { diagnosis }\end{array}$ & Final diagnosis \\
\hline 78 & Left & 3 & Malignant & Seminoma \\
38 & Right & 2.5 & Malignant & Mixed GCT (EC+S) \\
21 & Left & 3 & Malignant & Mixed GCT (EC+YST) \\
19 & Right & 2 & Malignant & Embryonal carcinoma \\
49 & Right & 10 & Malignant & DLBCL \\
1 & Left & 5 & Malignant & Yolk sac tumor \\
9 & Right & 0.8 & Benign & Epidermoid cyst \\
25 & Right & 4 & Malignant & Seminoma \\
41 & Left & 1 & Malignant & Teratoma \\
21 & Left & 1 & Benign & Epidermoid cyst \\
64 & Right & 1.5 & Benign & Hemangioma \\
6 & Right & 1.5 & Benign & Epidermoid cyst \\
62 & Right & 3 & Benign & Leiomyoma \\
16 & Right & 1.5 & Benign & Epidermoid cyst \\
25 & Right & 7.5 & Malignant & Seminoma \\
22 & Left & 3 & Mailgnant & Yolk sac tumor \\
68 & Right & 3 & Benign & Epidermoid cyst \\
\hline GCT: Germ cell tumor, EC: Embryonal carcinoma, S: Seminoma, YST: Yolk sac tumor, DLBCL: Diffuse \\
large B-cell lymphoma
\end{tabular}

\section{DISCUSSION}

Testicular cancer is the most common cancer of the genital system in men. Approximately 50000 new cases and 10000 deaths are detected every year in the world. ${ }^{[2]}$ In the last few decades, an increase has been observed in the incidence of testicular cancer all over the world, mainly in European countries. However, with early diagnosis, standardization of tumor management and advances in treatment, a significant decrease in mortality rates has been detected. It is seen that the five-year survival rates have increased from $63 \%$ to over $90 \% .^{[1]}$ The etiology of testicular tumors is not clear, and environmental and genetic factors play a role. Cryptorchidism is one of the most important risk factors and the rate of development of testicular cancer is 2.9-6.3\%. ${ }^{[8]}$ Age, family history of testicular tumor, the white race, 
high socioeconomic level, testicular microlithiasis, trauma, infection, exposure to in utero diethylstilbestrol, mother's smoking during pregnancy, occupational exposures, chemicals, diet rich in fat and dairy products are among the risk factors. ${ }^{[2,3,8]}$ Testicular tumors are most common in the 15-40 years age range. The mean age of the patients in our series was 37.9 years, and it was consistent with the literature. ${ }^{[1,2]}$ Right side testicular tumor involvement is more common than the left side. The frequency of bilateral testicular tumor involvement is $1-4 \%$. Bilateral tumors can be observed simultaneously (synchronous) or at different times (metachronous) ${ }^{[6]}$ Right side involvement was more common in our cases, and bilateral testicular involvement was not observed.

Approximately $90-95 \%$ of testicular tumors consist of GCTs. In our series, $53(81.7 \%)$ of 65 cases were GCT. Seminomas are the most common observed among testicular tumors. Seminomas constituted 22 (33.9\%) of our cases (Figure 2), in addition they were found at a rate of $58 \%$ of the components that made up mixed GCTs (Table 2). Radiotherapy is used for the treatment of seminomas and has no place for the treatment of other GCTs, so in the presence of testicular tumor, correct diagnosis of seminomas is important in terms of treatment and prognosis. It has been reported that the biological behaviors of anaplastic seminomas with high mitotic activity do not change the prognosis and treatment of the patient and therefore do not need to be specified in pathology reports. ${ }^{[9,10]}$ Although the rate of embryonal carcinoma in mixed GCTs is over $80 \%$, its pure form is rarely seen $(2-10 \%){ }^{[5,9]}$ Pure embryonal carcinoma was detected in one of our cases (1.5\%) and embryonal carcinoma was available in $89.7 \%$ of mixed GCTs in our cases. Although yolk sac tumor is rarely seen (1\%), it is the most common observed testicular tumor of the prepubertal period. In children, its pure form is seen. Its pure form is rare in adults and it is found as a component of mixed GCTs, with a rate of $40 \%{ }^{[11]}$ One of our three cases diagnosed as yolk sac tumor was in the prepubertal period and he was 1 year old, the others were 22 and 38 years old. In $68.4 \%$ of our mixed GCT cases, yolk sac tumor component was available. Pure form of choriocarcinoma is rare and accounts for less than $1 \%$ of testicular tumors. Finding the vital tumor area becomes difficult due to the widespread presence of bleeding and necrosis. Vascular invasion is an important feature of choriocarcinoma. ${ }^{[11,12]}$ In one of our cases, pure choriocarcinoma was seen and choriocarcinoma was available as a component of mixed GCT in our another case. The age of our pure choriocarcinoma case was 21 years. He was diagnosed as lung metastasis before, and then it was detected that the primary was testis. Microscopic examination revealed that the entire testis was hemorrhagic and necrotic in appearance, there were tumor cells with pleomorphic bizarre nuclei in limited areas, frequent mitosis and widespread vascular invasion (Figure 4). Teratomas are rarely seen as pure and constitute $2-3 \%$ of GCTs. They accompany mixed GCTs at a rate of approximately $50 \%$. In our series, pure teratoma was observed in a 41-yearold patient. The rate of teratoma accompanying mixed GCTs was $52.7 \%$ in our cases. While prepubertal teratomas show benign behavior, it is considered that postpubertal teratomas show malignant behavior. ${ }^{[10,11]}$ Mixed GCTs, which are composed of different combinations of GCT subtypes, constitute approximately half of the testicular GCTs. In our series, the rate of mixed GCTs to all testicular tumors was low, with the rate being 29.3\% (Table 1). Among the most common combinations there are embryonal carcinoma+teratoma, embryonal carcinoma+seminoma, embryonal carcinoma+yolk sac tumor+teratoma, embryonal carcinoma+teratoma+choriocarcinoma. Embryonal carcinoma is the most common accompanying component to combinations (Figure 3) ${ }^{[3,11]}$ In our series, combination of embryonal carcinoma+yolk sac tumor+teratoma was the most frequently observed (Table 2). Spermatocytic tumor constitutes $1-2 \%$ of GCTs. Average age of occurrence is $52-$ 59 years. ${ }^{[3]}$ In our series, one case (1.5\%) with a diagnosis of spermatocytic tumor was available and the age was 47 years. Epidermoid cyst accounts for $1-2 \%$ of all testicular tumors and is the most common benign tumor of the testicle. It is frequently seen between the second and fourth decades. It has an average diameter of $2 \mathrm{~cm}$ and is mostly observed in the right testicle. It is difficult to distinguish from malignant tumors clinically, and the definitive diagnosis is made by histopathological examination. Intraoperative frozen section examination is useful in determining radical orchiectomy or testicular preserving surgery option for treatment of epidermoid cyst. ${ }^{[13]}$ Four of our five cases diagnosed as epidermoid cyst were localized in the right testicle, and the mean tumor diameter was $1.6 \mathrm{~cm}$. Intraoperative frozen section examination was performed in all of our cases, and testicular preserving surgery was performed because their frozen section diagnoses were benign.

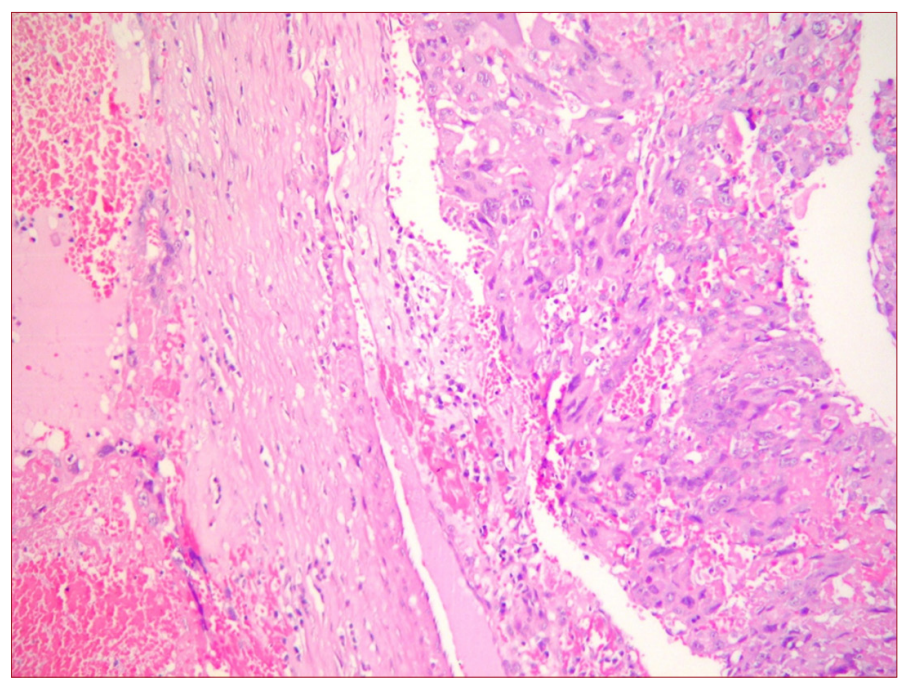

Figure 4. Choriocarcinoma. Hemorrhage, areas of necrosis and vascular invasion of pleomorphic tumor cells. (HE x 100) 
Sex cord-stromal tumors account for $8 \%$ of all testicular tumors. Leydig cell tumor, which is the most common seen in this group, constitutes $1-3 \%$ of all testicular tumors. ${ }^{[11,14]}$ Leydig cell tumor was detected in 2 (3.1\%) of our cases, but other tumor types were not observed. Lymphomas are the most common testicular neoplasms of patients over the age of 60 years. It is seen in 1-9\% of all testicular tumors. The most common type is diffuse large B-cell lymphoma with a rate of $80-90 \% .{ }^{[15]}$ Diffuse large B cell lymphoma was observed in $4(6.2 \%)$ of our cases. Three of these cases were over 60 years old. In our series, an adenomatoid tumor located in the paratesticular area was observed in one case who was sent for consultation. Adenomatoid tumor is the most common paratesticular neoplasm. It accounts for approximately 30\% of all paratesticular masses. ${ }^{[3,16]}$ Mesenchymal tumors may develop from interstitial mesenchymal cells and endothelial cells of the spermatic cord and testicular adnexa. In our series, one case each with a diagnosis of hemangioma, leiomyoma and leiomyosarcoma was observed. Secondary tumors of the testis are extremely rare, they are seen at a rate of $0.06-3.6 \%$. The most common metastasis to the testicle originate from the prostate, gastrointestinal tract, kidney, lung, malignant melanoma and urinary tract. In children, neuroblastoma, Willms tumor and rhabdomyosarcoma metastases are seen. ${ }^{[3]}$ In our cases, malignant melanoma metastasis was observed in a 76-year-old patient and renal cell carcinoma metastasis in a 56-year-old patient.

Most of the testicular tumors are GCTs diagnosed with clinical and radiological findings before surgery. With the increasing use of scrotal USG, the diagnosis of small-sized and nonpalpable testicular lesions has increased. It has been shown that $80 \%$ of these lesions are benign. Scrotal ultrasonography does not have sonographic features to precisely distinguish intratesticular tumors as benign and malignant. The correct and definite distinction between benign and malignant lesions is only possible with histopathological examination. Frozen section examination is a very sensitive and specific intraoperative procedure to distinguish testicular and paratesticular tumors as benign and malignant. There are few studies suggesting that frozen examination can be accurate and effective to avoid radical orchiectomy. Silverio et al. retrospectively analyzed frozen section examination results and the biopsy permanent sections of 170 patients diagnosed as testicular lesions during fourteen years. As a result, they determined that frozen section examination helped to prevent unnecessary radical orchiectomy in $46(88.5 \%)$ of cases with nonmalignant lesions. ${ }^{[17,18]}$ Frozen section examination is an important diagnostic method in determining the preference of organ-preserving surgery or radical orchiectomy surgical methods for childhood testicular tumors. ${ }^{[19]}$ In our series, frozen section examination was performed in 17 cases, and organ preserving surgery was performed in 7 cases whose frozen diagnosis was benign (Table 3).

\section{CONCLUSION}

As a result, the majority of our series of 65 cases with testicular tumors in our 15-year archive consisted of GCTs by being in accordance with the literature, and most of these were seminomas and mixed GCTs. We think that further studies should be done to emphasize that intraoperative frozen section examination is an important diagnostic method in terms of organ preserving surgery.

\section{ETHICAL DECLARATIONS}

Ethics Committee Approval: For this research; Tokat Gaziosmanpaşa University Faculty of Medicine Clinical Research Ethics Committee approval was obtained (Date: 28.01.2021, number 20-KAEK-320)

Informed Consent: Because the study was designed retrospectively, no written informed consent form was obtained from patients.

Referee Evaluation Process: Externally peer-reviewed.

Conflict of Interest Statement: The authors have no conflicts of interest to declare.

Financial Disclosure: The authors declared that this study has received no financial support.

Author Contributions: All of the authors declare that they have all participated in the design, execution, and analysis of the paper, and that they have approved the final version.

\section{REFERENCES}

1. Shanmugalingam T, Soultati A, Chowdhury S, Rudman S, Hemelrijck MV. Global incidence and outcome of testicular cancer. Clin Epidemiol 2013;5:417-27.

2. Kalan Farmanfarma KH, Mahdavifar N. Mohammadian-Hafshejani A Salehiniya $\mathrm{H}$. Testicular cancer in the world:an epidemioological review. WCRJ 2018;5(4):e1180.

3. Moch H, Humphrey PA, Ulbright TM, Reuter VE. WHO Classification of Tumours of the Urinary System and Male Genital Organs. 4th ed. IARC. Lyon, 2016.

4. Smith ZL, Werntz RP, Eggener SE. Testicular Cancer Epidemyology, Diagnosis and Management. Med Clin North Am 2018;102(2):251-64.

5. Yalçınkaya U, Çalışır B, Uğraş N, Filiz G, Erol O. Testis tümörleri:30 yıllık arşiv tarama sonuçları. Türk Patoloji Derg 2008;24(2);100-6.

6. Che M, Tamboli P, Ro JY, et al. Bilateral testicular germ cell tumors twentyyear experience at M.D. Anderson Cancer Center. Cancer 2002;95:122833.

7. Moch H, Cubilla AL, Humphrey PA, Reuter VE, Ulbright TM. The 2016 WHO Classification of Tumours of the Urinary System and Male Genital OrgansPart A:Renal, Penile and Testicular Tumours. Eur Urol 2016;70(1):93-105.

8. Baird DC, Meyers GJ. Testicular Cancer:Diagnosis and Treatment. Am Fam Physician 2018;97(4):261-8.

9. Yörükoğlu K. Testis tümörlerinde prognozu belirleyen histopatolojik parametreler. Üroonkoloji Bülteni 2011:3;91-4.

10. Willamson SR, Delahunt B, Magi-Galluzi C, et al. The World Health Organization 2016 classification of testicular germ cell tumours:a review and update from the International Society of Urological Pathology Testis Consultation Panel. Histopathology 2017;70:335-46.

11. Yörükoğlu K, Sarsık B. Testis, Spermatik kord ve testis ekleri. In Yörükoğlu K, Tuna. Üropatoloji. İzmir, Kongre Kitabevi 2016;475-611. 
12. Alvarado-Cabrero I, Hernandez-Toriz N, Paner GP. Clinicopathologic Analysis os Choriocarcinoma as a Pure or Predominant Component of Germ Cell Tumor of Testis. Am J Surg Pathol 2014;38:111-8.

13. Onuk Ö, Yanaral F, Gezmiş T, Demir K, Aydın M, Nuhoğlu B. A rare testicular tumor:epidermoid cyst. New J Urol 2016;11(3):46-9.

14. Cornejo KM, Young RH. Sex cord-stromal tumors of the testis. Diagnostic Histopathology Special Issue:Nephrourology 2019;25(10):398-407.

15. Chen B, Cao DH, Lai L, et al. Adult primary testicular lymphoma:clinical features and survival in a series of patients treated at a high-volume institution in China. BMC Cancer 2020;20:220:1-11.

16. Amin W, Parwani AV. Adenomatoid Tumor of Testis. Clin Med Pathol 2009;2;17-22.

17. Silverio PC, Schoofs F, Iselin CE, Tille JC. Fourteen-year experience with the intraoperative frozen section examination of testicular lesion in a tertiary university center. Ann Diagn Pathol 2015;19(3);99-102.

18. Giannarini G, Dieckman KP, Albers P, Heidenreich A, PizzocaroG. OrganSparing Surgery for Adult Testicular Tomours:A Systematic Review of the Literature. European Urology 2010;57:780-790.

19. Bıçakçı Ü, Demirel D, Hancıoğlu S, Arıtürk E, Bernay F. Childhood testicular tumors. J Contemp Med 2018;8(1):34-6. 